\title{
Combination of Hot Water and Ethanol to Control Postharvest Decay of Peaches and Nectarines
}

\author{
Dennis A. Margosan, Plant Pathologist, Joseph L. Smilanick, Research Plant Pathologist, Gilbert F. Simmons, \\ Research Associate, and Delmer J. Henson, Biological Aide, Horticultural Crops Research Laboratory, Agricul- \\ tural Research Service, U. S. Department of Agriculture, 2021 S. Peach Avenue, Fresno, CA 93727
}

\begin{abstract}
Margosan, D. A., Smilanick, J. L., Simmons, G. F., and Henson, D. J. 1997. Combination of hot water and ethanol to control postharvest decay of peaches and nectarines. Plant Dis. 81:14051409.

Spores of Monilinia fructicola or Rhizopus stolonifer were immersed in water or $10 \%$ ethanol $(\mathrm{EtOH})$ for $1,2,4$, or $8 \mathrm{~min}$ at temperatures of 46 or $50^{\circ} \mathrm{C}$ to determine exposure times that would produce $95 \%$ lethality (LT95). EtOH reduced the LT95 by about $90 \%$. Peaches and nectarines infected with M. fructicola were immersed in hot water alone or with EtOH to control decay. EtOH significantly increased the control of brown rot compared to water alone. Immersion of fruit in water at 46 or $50^{\circ} \mathrm{C}$ for 2.5 min reduced the incidence of decayed fruit from $82.8 \%$ to 59.3 and $38.8 \%$, respectively. Immersion of fruit in $10 \%$ ethanol at 46 or $50^{\circ} \mathrm{C}$ for 2.5 min further reduced decay to 33.8 and $24.5 \%$, respectively. Decay after triforine $\left(1,000 \mu \mathrm{g} \mathrm{ml}^{-1}\right)$ treatment was $32.8 \%$. Two treatments, $10 \% \mathrm{EtOH}$ at $50^{\circ} \mathrm{C}$ for $2.5 \mathrm{~min}$ and $20 \% \mathrm{EtOH}$ at $46^{\circ} \mathrm{C}$ for $1.25 \mathrm{~min}$, were selected for extensive evaluation. The flesh of EtOH-treated fruit was significantly firmer, approximately $4.4 \mathrm{~N}$ force, than that of control fruit among seven of nine cultivars evaluated. No other factor evaluated was significantly influenced by heated EtOH treatments. The EtOH content of fruit treated with 10 or $20 \% \mathrm{EtOH}$ was approximately 520 and 100 $\mu \mathrm{g} \mathrm{g}^{-1} 1$ day and 14 days after treatment, respectively.
\end{abstract}

Additional keywords: brown rot, ethyl alcohol, heat treatment, Prunus persica, Rhizopus rot

Brown rot and Rhizopus rot (causal organisms, Monilinia fructicola [Wint.] Honey and Rhizopus stolonifer [Ehrenb.:Fr.] Vuill, respectively) are two important postharvest diseases of nectarines and peaches in California. Postharvest losses are 5-10\% when postharvest fungicides are used (6); without fungicides, losses of $50 \%$ or higher have occurred in some years. For example, in a 1993 test to assess the decay potential of stone fruit, an average of $52.8 \%$ (range $15-100 \%)$ of the fruit decayed during the ripening of eight collections that had not been treated with postharvest fungicides (unpublished data).

Fungicides registered for postharvest use include thiabendazole and dichloran. Interest in developing alternatives to these fungicides is high because they are being lost due to fungicide resistance, regulatory issues, and growers or consumers who may prefer not to use them. Iprodione, a very effective fungicide for this application, became unavailable for this use in April 1996.

Corresponding author: D. A. Margosan

E-mail: A03dmargosan@attmail.com

Accepted for publication 4 August 1997.

Publication no. D-1997-0904-02R

This article is in the public domain and not copyrightable. It may be freely reprinted with customary crediting of the source. The American Phytopathological Society, 1997.
The efficacy of hot water treatments to reduce decay and the viability of Monilinia and Rhizopus spores is known $(22,24,28)$. Hot water reduces decay substantially, but the risk of injury, weight loss, and the lack of antifungal residues has made this treatment a less attractive option than the relative ease of application, efficacy, and persistent protection offered by fungicides $(15,23,25,28)$.

Ethanol (EtOH) occurs naturally in fruit and many other food products, and its toxicological properties have been thoroughly studied (1). EtOH without heat has been tested for control of brown rot $(7,14)$ and Rhizopus rot (14) with varying degrees of success. In a preliminary report, Margosan and coworkers (11) combined heat and $\mathrm{EtOH}$ to reduce the incidence of postharvest brown rot of peaches. Our objectives were to evaluate hot water combined with $\mathrm{EtOH}$ for the control of postharvest decay and its influence on fruit quality and $\mathrm{EtOH}$ content.

\section{MATERIALS AND METHODS}

Fruit. Peaches and nectarines were obtained from packinghouses in the San Joaquin Valley of central California. Fruit without visible injuries were selected by hand from field bins immediately after harvest. If the fruit were not used on the day of collection, they were stored at $0^{\circ} \mathrm{C}$ until use the next day.

Fungi. M. fructicola (ATCC 44557) was grown on potato-dextrose agar (PDA) for 2 weeks with a daily cycle of $15^{\circ} \mathrm{C}$ in darkness for $12 \mathrm{~h}$ and $25^{\circ} \mathrm{C}$ in fluorescent light for $12 \mathrm{~h}$; R. stolonifer, a gift from T. J. Michailides, was grown on PDA for 2 weeks at $20^{\circ} \mathrm{C}$ in constant darkness. Spores were collected from five culture plates by adding approximately $10 \mathrm{ml}$ per plate of cold sterile distilled water with $0.03 \mathrm{~g}$ of Tween 20 and rubbing the colony surface with a glass rod. The resulting spore suspension was filtered through several layers of cheesecloth. The suspension was centrifuged twice at $1,300 \times g$ for $60 \mathrm{~s}$, the supernatant discarded, and the pellet resuspended in fresh distilled water.

Spore mortality. To determine the rate at which spores died in heated water or EtOH solutions, spores were immersed in the solutions and their germination assessed afterward. Spores were collected as described previously. The suspensions were transferred to $25 \times 150 \mathrm{~mm}$ glass test tubes suspended in a water bath at 45 or $50^{\circ} \mathrm{C}$. Temperatures in the water bath and treatment tubes were monitored by thermocouples connected to a data recorder (Polycorder, Omnidata International, Inc., Logan, UT). Each tube contained $25 \mathrm{ml}$ of test solution at a concentration of $1.5 \times 10^{3}$ spores $\mathrm{ml}^{-1}$. After 1, 2, 4, and $8 \mathrm{~min}$, approximately $5 \mathrm{ml}$ of spore suspension was removed with a pipette and transferred to a glass test tube containing $5 \mathrm{ml}$ of water at $1^{\circ} \mathrm{C}$ in an ice bath. The total time spores were in water or test solutions before or after heat treatment was constant among all treatments. Spores were washed by the method previously described and resuspended in sterile water. Four drops of suspension from each treatment were placed in succession $90^{\circ}$ from the previous drop on each of two water agar plates, the plates were incubated at $20^{\circ} \mathrm{C}$ for $24 \mathrm{~h}$, and 400 spores from each treatment were examined microscopically for germination. A spore was classified as germinated if the length of the germ tube was equal to or greater than the diameter of the spore. The estimated time in seconds to kill $95 \%$ of the spores was determined by Finney's probit analysis (8) using germination values from three experiments, each containing two replicates of 200 spores, for a total of 1,200 spores.

Decay control. In 1992, experiments to determine optimum $\mathrm{EtOH}$, time, and temperature combinations were conducted with four cultivars. High spore densities 
are usually not present on early-season fruit (16), thus necessitating artificial inoculation to ensure adequate levels of decay for evaluating treatments. The early season nectarine May Grand (Prunus persica var. nectarina) was artificially inoculated by spraying water suspensions of $M$. fructicola spores on the fruit about $1 \mathrm{~h}$ before treatment. The fruit were randomized and then inoculated using a hand sprayer; $3 \times 10^{4}$ spores per fruit were applied. The fruit were dry in air prior to treatment. The high natural incidence of postharvest decay of mid- to late-season fruit made artificial inoculation of nectarines (cv. Fantasia) and peaches (cvs. O'Henry and Autumn Lady) unnecessary. Naturally infected fruit were used rather than artificially infected fruit, because $M$. fructicola infections are not limited to surface-borne spores but include quiescent infections of preharvest origin that would be difficult to simulate $(4,12,13,26,27)$.

In 1992, to determine optimum treatment regimes, heat and EtOH treatments were applied to 100 fruit in replicates of 20 or 25 each. They were immersed for 2.5 $\min$ in $15 \mathrm{~L}$ of water or $2.5,5,10$, or $20 \%$ $\mathrm{EtOH}$ heated to 46,50 , or $52^{\circ} \mathrm{C}$ in glass tanks. The tanks were immersed in a $300-\mathrm{L}$ temperature-controlled water bath. Bath temperatures were monitored during treatment and did not change more than $\pm 1^{\circ} \mathrm{C}$. Fruit pulp temperature at the time of treatment was $18^{\circ} \mathrm{C}\left( \pm 1^{\circ} \mathrm{C}\right)$. Control treatments included dry, untreated fruit and fruit dipped for $1 \mathrm{~min}$ in $600 \mu \mathrm{g} \mathrm{ml}{ }^{-1}$ triforine (Funginex, $18.2 \%$ a.i., Ciba-Geigy, Greensboro, NC) or $1,000 \mu \mathrm{g} \mathrm{m} \mathrm{m}^{-1}$ iprodione (Rovral, $50 \%$ a.i., Rhone-Poulenc, Research Triangle Park, NC). After treatment the fruit were placed in plastic trays,

Table 1. Estimated time (s) to kill $95 \%$ of the spores of Monilinia fructicola or Rhizopus stolonifer in water alone or $10 \%$ ethanol at 46 or $50^{\circ} \mathrm{C}$

\begin{tabular}{lccccc}
\hline & \multicolumn{2}{c}{ M. fructicola } & & \multicolumn{2}{c}{ R. stolonifer } \\
\cline { 2 - 3 } \cline { 5 - 6 } Treatment & $\mathbf{4 6}^{\circ} \mathbf{C}$ & $\mathbf{5 0}^{\circ} \mathbf{C}$ & & $\mathbf{4 6}^{\circ} \mathbf{C}$ & $\mathbf{5 0}^{\circ} \mathbf{C}$ \\
\hline Water & $734.0 \mathrm{a}^{\mathrm{z}}$ & $206.3 \mathrm{a}$ & & $>1000.0 \mathrm{a}$ & $410.3 \mathrm{a}$ \\
$10 \%$ ethanol & $57.4 \mathrm{~b}$ & $7.0 \mathrm{~b}$ & & $94.4 \mathrm{~b}$ & $46.3 \mathrm{~b}$ \\
\hline
\end{tabular}

${ }^{\mathrm{z}}$ Each value was determined by Finney's probit analysis using mortality values from three experiments containing four replicates of 100 spores each. Values followed by unlike letters are significantly different $(P \leq 0.05)$.

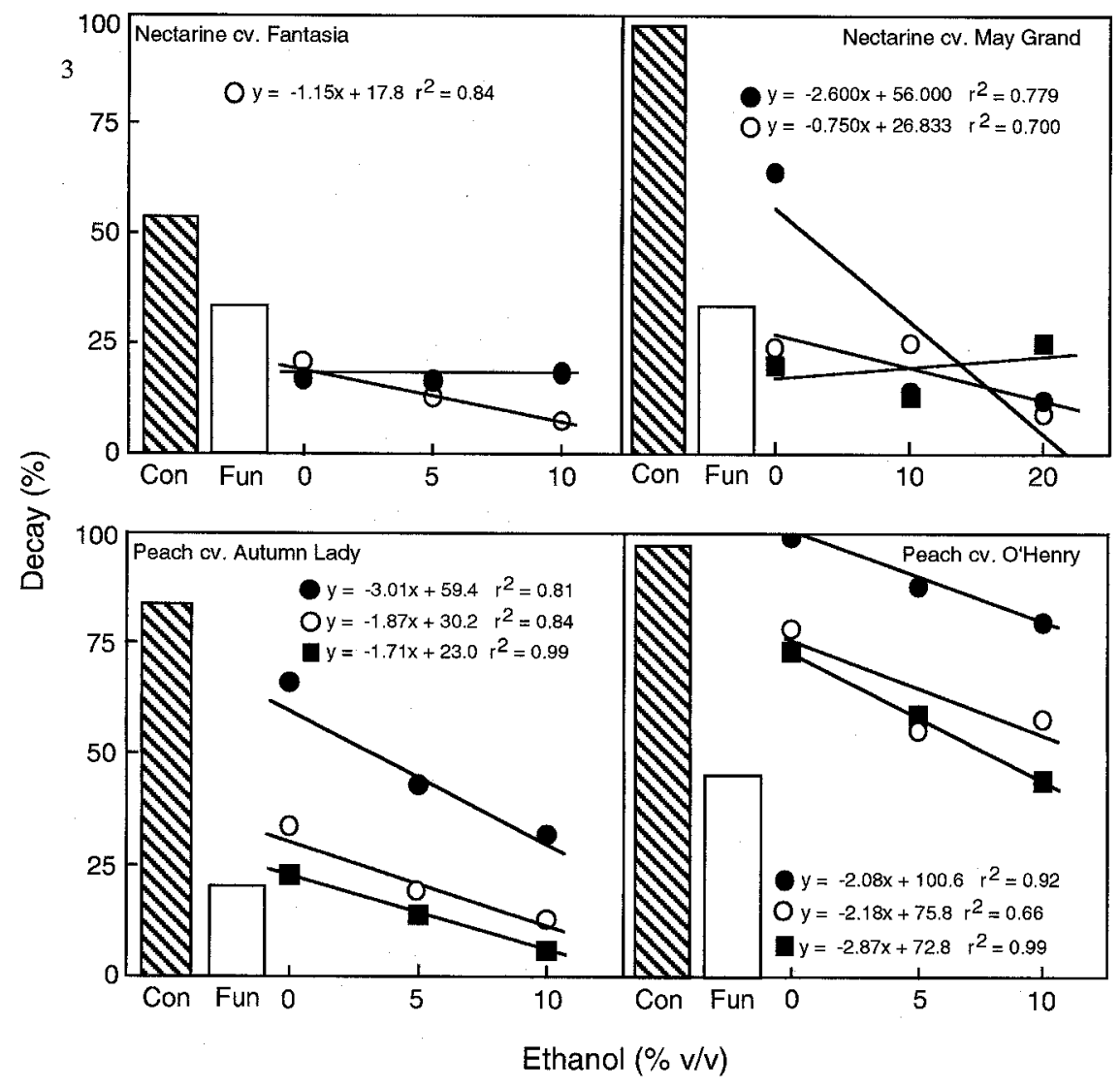

Fig. 1. The incidence of decayed peaches and nectarines after immersion for $2.5 \mathrm{~min}$ in $0,5,10$, or $20 \%$ ethanol at $46^{\circ} \mathrm{C}(\bullet), 50^{\circ} \mathrm{C}(\mathrm{O})$,or $52^{\circ} \mathrm{C}(\boldsymbol{\square})$, immersion for $1 \mathrm{~min}$ in iprodione or triforine (solid white bar) or an untreated control (hatched bar) and storage for 4 days at $20^{\circ} \mathrm{C}$. loosely sealed with a plastic bag, stored at $0-1{ }^{\circ} \mathrm{C}$ for 14 days, and then at $20^{\circ} \mathrm{C}$ for 4 days before the fruit were evaluated. Fruit with lesions of any size were classified as decayed.

In 1993, the influence of treatment duration was evaluated. Peach cultivars Spring Crest, Flavor Crest, and Elegant Lady were inoculated, treated for 1.25 or 2.5 min with 10 or $20 \% \mathrm{EtOH}$ at 46 or $50^{\circ} \mathrm{C}$, and incubated as described previously. The number of decayed fruit and the number of lesions on each fruit were recorded.

Data were analyzed using a one- or twoway ANOVA. Percentage data were arcsine transformed before analysis, although the actual data are reported. Means were separated by Fisher's protected least significant difference test $(P \leq 0.05)$ or by orthogonal contrasts.

Quality evaluation. To evaluate the influence of $\mathrm{EtOH}$ on fruit quality, nine noninoculated cultivars were treated as follows: 1) $10 \% \mathrm{EtOH}$ at $50^{\circ} \mathrm{C}$ for $150 \mathrm{~s}$, 2) $20 \% \mathrm{EtOH}$ at $46^{\circ} \mathrm{C}$ for $75 \mathrm{~s}, 3$ ) water at $46^{\circ} \mathrm{C}$ for $\left.75 \mathrm{~s}, 4\right)$ water at $50^{\circ} \mathrm{C}$ for $150 \mathrm{~s}$, or 5) not treated (control). For each test, 40 fruit were treated, placed in plastic trays, loosely sealed with a plastic bag, stored at $1 \pm 1^{\circ} \mathrm{C}$ for 14 days and then at $20^{\circ} \mathrm{C}$ for 4 days, and then evaluated. Twenty fruit were selected from each treatment for quality evaluation: 1) $L^{*}, a^{*}$, and $b^{*}$ color values on two sides were determined with a tristimulus colorimeter with an $8-\mathrm{mm}$

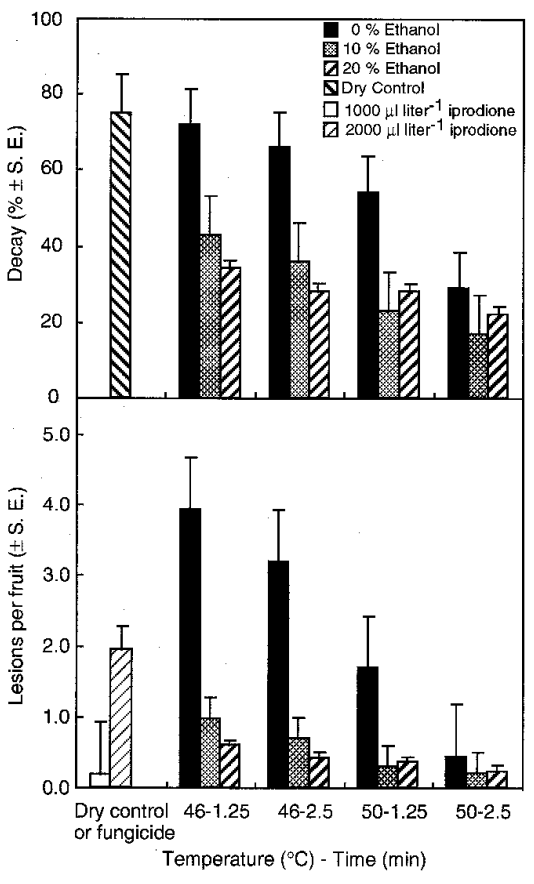

Fig. 2. The incidence of decayed fruit and the number of lesions per fruit of three peach cultivars after immersion for $1.25 \mathrm{~min}$ (top) or 2.5 min (bottom), in water alone, or in $10 \%$ or $20 \%$ ethanol at 46 or $50^{\circ} \mathrm{C}$ and storage for 4 days at $20^{\circ} \mathrm{C}$. 
aperture (Minolta model DP301, Osaka, Japan); 2) soluble solids content was determined with a refractometer (Leica, Rochester, NY); and 3) firmness was measured on two sides of each fruit using a University of California pressure tester with a 6-mm-diameter puncture point.

Ethanol residue analysis. The $\mathrm{EtOH}$ content of seven cultivars of peaches and nectarines was measured within 1 day after treatment and after storage for 14 days at $0-1{ }^{\circ} \mathrm{C}$ and 4 days at $20^{\circ} \mathrm{C}$. The $\mathrm{EtOH}$ analysis was done using the Sigma alcohol (ethanol) diagnostic kit, procedure No. 332-UV (Sigma Diagnostics, St. Louis, MO). Three or four fruit per treatment were selected, quartered, and juiced in an electric juicer fitted with a paper filter. The juice was passed through a $0.45-\mu \mathrm{m}$ pore filter before analysis. A 10- $\mu$ aliquot of filtered juice was added to $3 \mathrm{ml}$ of $0.5 \mathrm{M}$ glycine buffer, the contents were mixed, incubated for $10 \mathrm{~min}$ at room temperature $\left(23 \pm 1^{\circ} \mathrm{C}\right)$, and the absorption measured with a spectrophotometer $(\lambda=340 \mathrm{~nm})$. EtOH concentration was determined from a standard curve prepared from the analysis of known EtOH concentrations.

\section{RESULTS}

Spore mortality. Spore mortality occurred much more quickly in heated EtOH than it did in heated water (Table 1). Ninety-five percent spore mortality (LT95) was achieved in less time at $50^{\circ} \mathrm{C}$ than at $46^{\circ} \mathrm{C}$ for both fungi (Table 1). Ten percent EtOH at 46 or $50^{\circ} \mathrm{C}$ greatly reduced the LT95 of both $M$. fructicola or $R$. stolonifer. At 46 and $50^{\circ} \mathrm{C}$ for $M$. fructicola, and at $46^{\circ} \mathrm{C}$ for $R$. stolonifer, $10 \% \mathrm{EtOH}$ reduced the LT95 by a factor of 10 compared to water; slightly less than a ten-fold reduction in LT95 time was recorded with $R$. stolonifer spores immersed at $50^{\circ} \mathrm{C}$.

Decay control. Water treatment at 50 and $52^{\circ} \mathrm{C}$ significantly reduced decay in four experiments to determine optimal $\mathrm{EtOH}$ concentration, treatment temperature, and immersion time (Fig. 1). The addition of EtOH significantly improved control of decay compared with hot water treatment. Treatments of $10 \% \mathrm{EtOH}$ at $50^{\circ} \mathrm{C}$ or $20 \% \mathrm{EtOH}$ at $46^{\circ} \mathrm{C}$ reduced decay to $25 \%$ (average of four cultivars) and $12 \%$ (one cultivar), respectively, from $83 \%$ decay among untreated controls. A 1-min dip in iprodione $\left(1,000 \mu \mathrm{g} \mathrm{ml}^{-1}\right)$ reduced decay to $33 \%$ (mean of four cultivars) (Fig. 1). No injury to the fruit was observed after any treatment.

EtOH enhanced control of decay at the treatment times and temperatures evaluated particularly when the number of lesions per fruit was counted in three experiments

Table 2. Summary of analysis of variance of postharvest decay incidence and lesions per fruit among three cultivars (Flavor Crest, Spring Crest, Elegant Lady) after immersion for 1.25 or $2.5 \mathrm{~min}$, in water alone, or in $10 \%$ or $20 \%$ ethanol at 46 or $50^{\circ} \mathrm{C}$, and storage for 4 days at $20^{\circ} \mathrm{C}$

\begin{tabular}{|c|c|c|c|c|c|}
\hline \multirow[b]{2}{*}{ Source of variation } & \multirow[b]{2}{*}{ df } & \multicolumn{2}{|c|}{ Decay incidence } & \multicolumn{2}{|c|}{ Lesion per fruit } \\
\hline & & Mean square & $F$-value ${ }^{\mathrm{z}}$ & Mean square & $F$-value $^{\mathrm{z}}$ \\
\hline Cultivar & 2 & 8.11 & $213.39 * * *$ & 36.61 & $21.75^{* *}$ \\
\hline Time (A) & 1 & 0.87 & $22.96 * * *$ & 7.09 & $4.21 *$ \\
\hline Temperature (B) & 1 & 1.60 & $42.13 * * *$ & 43.08 & $25.59 * * *$ \\
\hline EtOH Conc. (C) & 2 & 1.70 & $44.79 * * *$ & 53.97 & $32.06 * * *$ \\
\hline $\mathrm{A} \times \mathrm{B}$ & 2 & 0.00 & 0.01 & 0.06 & $0.08 * * *$ \\
\hline $\mathrm{A} \times \mathrm{C}$ & 2 & 0.12 & $3.13^{*}$ & 2.76 & 1.64 \\
\hline $\mathrm{B} \times \mathrm{C}$ & 2 & 0.25 & $6.59 * *$ & 17.94 & $10.66 * *$ \\
\hline $\mathrm{A} \times \mathrm{B} \times \mathrm{C}$ & 2 & 0.01 & 0.14 & 0.40 & 0.24 \\
\hline \multicolumn{6}{|l|}{ Orthogonal contrasts } \\
\hline $1.25 \mathrm{~min}$ vs. $2.5 \mathrm{~min}$ & 1 & 0.87 & $23.00 * * *$ & 7.09 & $4.21 *$ \\
\hline $46^{\circ} \mathrm{C}$ vs. $50^{\circ} \mathrm{C}$ & 1 & 1.60 & $42.13 * * *$ & 43.08 & $25.59 * * *$ \\
\hline $0 \%$ vs. $10 \%$ Ethanol & 1 & 2.34 & $60.73 * * *$ & 74.84 & $44.46 * * *$ \\
\hline $0 \%$ vs. $20 \%$ Ethanol & 1 & 2.76 & $71.66 * * *$ & 86.64 & $51.47 * * *$ \\
\hline $10 \%$ vs. $20 \%$ Ethanol & 1 & 0.02 & 0.45 & 0.43 & 0.26 \\
\hline Error & 135 & 0.04 & & 1.683 & \\
\hline
\end{tabular}

z ***,**, * Significant at $P \leq 0.001,0.01$, or 0.05 , respectively. to determine the influence of treatment time, EtOH concentration, and temperature on the incidence of decayed fruit and the number of lesions per fruit (Fig. 2). Treatment for $2.5 \mathrm{~min}$ was significantly superior to $1.25 \mathrm{~min}$ (Table 2), EtOH concentrations 10 and $20 \%$ were significantly superior to water alone, but not significantly different from each other, and treatment at $50^{\circ} \mathrm{C}$ was significantly superior to treatment at $46^{\circ} \mathrm{C}$.

Quality evaluation. Fruit treated with $\mathrm{EtOH}$ were significantly firmer than untreated fruit or fruit treated with water alone among seven of the nine cultivars evaluated (Table 3). Soluble solids content was not significantly influenced by heat or $\mathrm{EtOH}$ in seven of the nine cultivars (Table 4). In the remaining two cultivars, there was no consistent trend; treated Fairtime fruit had higher soluble solids values than those of the untreated control, whereas treated O'Henry fruit had lower soluble solids than did the untreated control. Surface color and internal appearance were not influenced by any treatment (data not shown). The surfaces of two EtOH-treated late nectarine cultivars shriveled slightly.

Ethanol residue analysis. The average EtOH content $( \pm$ SD) of all fruit treated with $20 \% \mathrm{EtOH}$ at $46^{\circ} \mathrm{C}$ for 1.25 min was $535 \pm$ 158 and $92.5 \pm 85 \mu \mathrm{g} \mathrm{ml}^{-1}$ for fruit analyzed within 1 day and after 18 days of storage, respectively. The average $\mathrm{EtOH}$ content of all fruit treated with $10 \% \mathrm{EtOH}$ at $50^{\circ} \mathrm{C}$ for $2.5 \mathrm{~min}$ was $504 \pm 121$ and $106 \pm 125 \mu \mathrm{g}$ $\mathrm{ml}^{-1}$ for fruit analyzed within 1 day and after 18 days of storage, respectively.

\section{DISCUSSION}

The combination of EtOH and hot water controlled postharvest decay of nectarines and peaches, usually equal to the fungicide treatments included in some tests. Compared to previous studies that used hot water alone $(25,28)$, equivalent efficacy could be obtained with temperatures as much as $6^{\circ} \mathrm{C}$ cooler when EtOH was added to the water. Injury to the fruit did not occur, no off-flavors or odors from the fruit were detected by the investigators, and the increased firmness of the fruit observed in most tests is probably a benefit.

The increase in decay control that occurred when water and EtOH were com-

Table 3. Firmness (Newtons) of peach and nectarine cultivars ${ }^{\mathrm{w}}$ after treatment followed by storage for 2 weeks at $1{ }^{\circ} \mathrm{C}\left( \pm 1^{\circ} \mathrm{C}\right)$ and 4 days at $20^{\circ} \mathrm{C}\left( \pm 1^{\circ} \mathrm{C}\right)$

\begin{tabular}{lcccccccccc}
\hline Treatment $^{\mathbf{x}}$ & Temp. $\left({ }^{\circ} \mathbf{C}\right)$ & $\mathbf{1}$ & $\mathbf{2}$ & $\mathbf{3}$ & $\mathbf{4}$ & $\mathbf{5}$ & $\mathbf{6}$ & $\mathbf{7}$ & $\mathbf{8}$ & $\mathbf{9}$ \\
\hline Initial $^{\mathrm{y}}$ & NA & 50.2 & 41.8 & 58.8 & 48.9 & 60.1 & 44.0 & 50.1 & 43.6 \\
Untreated & NA & $24.3 \mathrm{a}^{\mathrm{z}}$ & $23.5 \mathrm{a}$ & $17.8 \mathrm{ab}$ & $33.8 \mathrm{ab}$ & $10.2 \mathrm{a}$ & $8.9 \mathrm{a}$ & $38.1 \mathrm{a}$ & $18.3 \mathrm{ab}$ & 44.0 \\
Water & 46 & $29.4 \mathrm{ab}$ & $23.6 \mathrm{a}$ & $20.4 \mathrm{~b}$ & $25.8 \mathrm{a}$ & $10.2 \mathrm{a}$ & $8.3 \mathrm{a}$ & $35.0 \mathrm{a}$ & $17.7 \mathrm{ab}$ & $39.5 \mathrm{a}$ \\
Water & 50 & $24.5 \mathrm{a}$ & $23.4 \mathrm{a}$ & $17.7 \mathrm{ab}$ & $26.2 \mathrm{a}$ & $10.3 \mathrm{a}$ & $8.3 \mathrm{a}$ & $39.2 \mathrm{a}$ & $16.2 \mathrm{a}$ & $41.7 \mathrm{ab}$ \\
$20 \% \mathrm{EtOH}$ & 46 & $33.6 \mathrm{~b}$ & $22.2 \mathrm{a}$ & $25.5 \mathrm{c}$ & $32.7 \mathrm{ab}$ & $14.6 \mathrm{c}$ & $14.4 \mathrm{~b}$ & $41.1 \mathrm{a}$ & $22.9 \mathrm{c}$ & $47.9 \mathrm{~b}$ \\
$10 \% \mathrm{EtOH}$ & 50 & $24.5 \mathrm{a}$ & $26.1 \mathrm{a}$ & $16.4 \mathrm{a}$ & $47.0 \mathrm{~b}$ & $12.3 \mathrm{~b}$ & $17.4 \mathrm{~b}$ & $36.9 \mathrm{a}$ & $20.2 \mathrm{bc}$ & $46.9 \mathrm{~b}$ \\
\hline
\end{tabular}

${ }^{\mathrm{w}}$ Cultivars: 1 = Flamekist; 2 = Flame Red; 3 = O'Henry; 4 = September Red; $5=$ Summer Lady; 6 = Fantasia; 7 = Carnival; $8=$ Fairtime; and $9=$ August Red.

${ }^{\mathrm{x}}$ Twenty fruit per treatment were not treated, or immersed for: 1) $1.25 \mathrm{~min}$ in water at $\left.46^{\circ} \mathrm{C} ; 2\right) 2.5 \mathrm{~min}$ in water at $\left.50^{\circ} \mathrm{C} ; 3\right) 1.25 \mathrm{~min}$ in $20 \%$ ethanol at $46^{\circ} \mathrm{C}$; or 4) $2.5 \mathrm{~min}$ in $10 \%$ ethanol at $50^{\circ} \mathrm{C}$.

y Initial values not included in ANOVA.

${ }^{\mathrm{z}}$ Values in columns followed by the same letter are not significantly different according to Fisher's protected least significance test at $P \leq 0.05$. 
bined may result from their affecting the same sites in the spore. In Phycomyces blakesleeanus, the site of heat lethality in the ungerminated spore is cytoplasmic, whereas in the germinated spore, heat first affects the nucleus (17). This finding differs from that of Baker and Smith (2), who found that germinated spores of $R$. stolonifer had severe nuclear and mitochondrial damage when treated at $52^{\circ} \mathrm{C}$ for $2.5 \mathrm{~min}$, whereas similarly treated $M$. fructicola spores had much less visible damage to the nuclei and mitochondria; they concluded that heat lethality could not be linked to a single event. Cabeca-Silva et al. (5) found that in actively growing Saccharomyces cerevisiae, the sites of heat lethality were the mitochondria and that EtOH enhanced the elimination of mitochondria (petite mutations). Low concentrations of $\mathrm{EtOH}$ can lower the temperature at which phospholipids undergo a phase change (18). The increase in in vitro spore mortality and decay control affected by adding $\mathrm{EtOH}$ may have resulted from the lowering of the phase-change temperature of the mitochondrial membranes by EtOH.

The concept of combining treatments targeted at the mitochondria of $M$. fructicola conidia in vitro was tested by Bussel and coworkers (3). In their experiments, heat treatment followed by anoxia interacted synergistically to increase $M$. fructicola conidial mortality, whereas anoxia followed by heat resulted in increased spore resistance to heat. The lack of oxygen prior to heat treatment may have induced fungistatis and rendered the mitochondria more resistant to heat than those actively involved in metabolic processes. Heat treatment followed by storage in controlled atmosphere $\left(0.5 \% \mathrm{O}_{2}, 5 \% \mathrm{CO}_{2}\right)$ at $0^{\circ} \mathrm{C}$ reduced decay in storage, but not after the fruit were removed from storage (23).

An unanticipated benefit of the $\mathrm{EtOH}$ treatment was a delay in softening during storage, which would extend shelf life. In seven of nine cultivars, fruit firmness was significantly greater in one or both of the EtOH treatments than in either untreated or water controls (Table 2). The difference in firmness among treatments may result from EtOH slightly retarding the fruit rip- ening process. The application of EtOH in vapor or liquid phase to other fruit retards ripening $(10,20)$ and it was proposed $\mathrm{EtOH}$ disrupts cell membranes associated with ethylene action (19).

EtOH residues were low after storage and should pose a minimal regulatory issue (1). The natural EtOH content of firm nectarines is $1-5 \mu \mathrm{g} \mathrm{g}^{-1} \mathrm{EtOH}$ while soft nectarines contained $100-230 \mu \mathrm{g} \mathrm{g}^{-1}$. The higher values are associated with very ripe fruit $(11,21)$. The average EtOH $( \pm$ SD) content of all fruit treated with $10 \% \mathrm{EtOH}$ at $50^{\circ} \mathrm{C}$ for $2.5 \mathrm{~min}$ was $106 \pm 125 \mu \mathrm{g} \mathrm{ml}^{-1}$ for fruit analyzed after 18 days of storage. These values are within the range of $\mathrm{EtOH}$ content of ripe nectarines but lower than that reported for fruit held under controlled atmospheres (21). EtOH content was below that associated with off-flavors in controlled atmosphere studies (9,21). EtOH occurs naturally in ripening stone and other fruit, and it is an approved preservative for some foods (1).

Some slight shrivel of the epidermis was observed on several late-season nectarines after treatment, 14 days storage, and 4 days ripening, presumably caused by water loss following removal of cuticular waxes. The addition of a postharvest wax should alleviate desiccation problems caused by cuticular wax extraction by the treatment.

Unlike fungicides, the hot water EtOH treatments do not deposit persistent antifungal residues, so protection of fruit from recontamination would become particularly important after treatment throughout the postharvest period. An obstacle to the implementation of hot water $\mathrm{EtOH}$ treatment is the probable need for a vapor abatement system (1). The technology to control EtOH vapors has been developed for the baking and wine industries and should be adaptable to the packinghouse. The addition of a hot EtOH treatment tank will result in added cost for equipment and energy to operate it and a delay in cooling fruit before storage.

In spite of these issues, postharvest hot EtOH treatment can offer an alternative where the loss of fungicides has occurred through pathogen resistance or regulatory actions.
ACKNOWLEDGMENTS

We thank the California Tree Fruit Agreement for financial assistance for this project.

\section{LITERATURE CITED}

1. Anonymous. 1993. Ethyl alcohol. Page 455 in: Title 21, Code of Federal Regulations, Food and Drugs, part 184, section 1293. U. S Government Printing Office, Washington, DC.

2. Baker, J. E., and Smith, W. E., Jr. 1970. Heatinduced ultrastructural changes in germinating spores of Rhizopus stolonifer and Monilinia fructicola. Phytopathology 60:869-874.

3. Bussel, J., Miranda, M., and Sommer, N. F. 1971. Response of Monilinia fructicola conidia to individual and combined treatments of anoxia and heat. Phytopathology 61:61-64.

4. Byrde, R. J. W., and Willetts, H. J. 1977. The Brown Rot Fungi of Fruit. Their Biology and Control. Pergamon Press, New York.

5. Cabeca-Silva, C., Madeira-Lopes, A., and van Uden, N. 1982. Temperature relations of ethanol-enhanced petite mutations in Saccharomyces cerevisiae: Mitochondria as targets of thermal death. FEMS Microbiol. Lett. 15:149-151.

6. Cappellini, R. A., and Ceponis, M. J. 1984. Postharvest losses in fresh fruits and vegetables. Pages 24-30 in: Postharvest Pathology of Fruits and Vegetables: Postharvest Losses in Perishable Crops. University of California, Berkeley.

7. Feliciano, A., Feliciano, A. J., Vendrusculo, J., Adaskaveg, J. E., and Ogawa, J. M. 1987. Efficacy of ethanol in postharvest benomylDCNA treatments for control of brown rot of peach. Plant Dis. 76:226-229.

8. Finney, D. J. 1971. Probit Analysis, 3rd ed. Cambridge Press, New York.

9. Ke, D., El-Wazir, F., Cole, B., Mateos, M. and Kader, A. A. 1993. Tolerance of peach and nectarine fruits to insecticidal controlled atmospheres as influenced by cultivar, maturity, and size. Postharv. Biol. Technol. 4:135146.

10. Kelly M. O., and Saltveit, M. E., Jr. 1988. Effect of endogenously synthesized and exogenously applied ethanol on tomato fruit ripening. Plant Physiol. 88:143-147.

11. Margosan, D. A., Smilanick, J. L., Simmons, G. F., and Henson, D. J. 1993. Postharvest hot water and ethanol treatments to control postharvest brown rot on peaches and nectarines. Biol. Cult. Tests 8:11.

12. Northover, J., and Cerkauskas, R. F. 1994 Detection and significance of symptomless latent infections of Monilinia fructicola in plum. Can. J. Plant Pathol. 16:30-36.

13. Ogawa, J. M., and English, H. 1991. Diseases of Temperate Zone; Tree Fruit and Nut Crops. Publ. 3345. University of California, Oakland, CA.

Table 4. Percentage of soluble solids in peach and nectarine cultivars ${ }^{w}$ after treatment followed by storage for 2 weeks at $1{ }^{\circ} \mathrm{C}\left( \pm 1^{\circ} \mathrm{C}\right)$ and 4 days at $20^{\circ} \mathrm{C}$ $\left( \pm 1^{\circ} \mathrm{C}\right)$

\begin{tabular}{lcccccccccc}
\hline Treatment $^{\mathbf{x}}$ & Temp. $\left({ }^{\circ} \mathbf{C}\right)$ & $\mathbf{1}$ & $\mathbf{2}$ & $\mathbf{3}$ & $\mathbf{4}$ & $\mathbf{5}$ & $\mathbf{6}$ & $\mathbf{7}$ & $\mathbf{8}$ & $\mathbf{9}$ \\
\hline Initial $^{\mathrm{y}}$ & $\mathrm{NA}$ & 10.7 & 8.4 & 9.8 & 10.8 & 11.2 & 9.5 & 12.5 & 10.7 & 11.6 \\
Untreated & NA & $11.8 \mathrm{a} \mathrm{a}^{\mathrm{z}}$ & $9.1 \mathrm{a}$ & $11.0 \mathrm{~b}$ & $10.9 \mathrm{a}$ & $10.6 \mathrm{a}$ & $10.4 \mathrm{a}$ & $11.9 \mathrm{a}$ & $10.4 \mathrm{a}$ & $11.4 \mathrm{a}$ \\
Water & 46 & $12.0 \mathrm{a}$ & $9.0 \mathrm{a}$ & $9.8 \mathrm{a}$ & $11.1 \mathrm{a}$ & $11.4 \mathrm{a}$ & $9.9 \mathrm{a}$ & $11.7 \mathrm{a}$ & $10.8 \mathrm{ab}$ & $11.3 \mathrm{a}$ \\
Water & 50 & $11.1 \mathrm{a}$ & $8.8 \mathrm{a}$ & $11.3 \mathrm{~b}$ & $10.9 \mathrm{a}$ & $11.3 \mathrm{a}$ & $10.4 \mathrm{a}$ & $11.3 \mathrm{a}$ & $11.4 \mathrm{~b}$ & $11.3 \mathrm{a}$ \\
$20 \% \mathrm{EtOH}$ & 46 & $11.2 \mathrm{a}$ & $8.7 \mathrm{a}$ & $10.6 \mathrm{ab}$ & $11.4 \mathrm{a}$ & $11.0 \mathrm{a}$ & $9.6 \mathrm{a}$ & $11.9 \mathrm{a}$ & $11.3 \mathrm{~b}$ & $11.5 \mathrm{a}$ \\
$10 \% \mathrm{EtOH}$ & 50 & $11.1 \mathrm{a}$ & $8.6 \mathrm{a}$ & $11.0 \mathrm{~b}$ & $11.1 \mathrm{a}$ & $10.8 \mathrm{a}$ & $10.0 \mathrm{a}$ & $11.8 \mathrm{a}$ & $11.4 \mathrm{~b}$ & $11.5 \mathrm{a}$ \\
\hline
\end{tabular}

${ }^{\mathrm{w}}$ Cultivars: 1 = Flamekist; 2 = Flame Red; 3 = O'Henry; 4 = September Red; $5=$ Summer Lady; 6 = Fantasia; 7 = Carnival; $8=$ Fairtime; and $9=$ August Red.

${ }^{x}$ Twenty fruit per treatment were not treated, or immersed for: 1) $1.25 \mathrm{~min}$ in water at $46^{\circ} \mathrm{C}$;2) 2.5 min in water at $50^{\circ} \mathrm{C}$; 3) 1.25 min in $20 \%$ ethanol at $46^{\circ} \mathrm{C}$; or 4) $2.5 \mathrm{~min}$ in $10 \%$ ethanol at $50^{\circ} \mathrm{C}$.

y Initial values not included in ANOVA.

${ }^{\mathrm{z}}$ Values in columns followed by the same letter are not significantly different according to Fisher's protected least significance test at $P \leq 0.05$. 
14. Ogawa, J. M., and Lyda, S. D. 1960. Effect of alcohols on spores of Sclerotinia fructicola and other peach fruit rotting fungi in California. Phytopathology 50:790-792.

15. Phillips, D. J., and Austin, R. K. 1982. Changes in peaches after hot-water treatment. Plant Dis. 66:487-488.

16. Phillips, D. J., and Harris, C. M. 1979. Postharvest brown rot of peaches and inoculum density of Monilinia fructicola (Wint.). U. S. Department of Agriculture. ARR-W-9.

17. Pueyo, C., and Cerda-Olmedo, E. 1981. Causes of cell death following exposure to different fungicides and heat. Exp. Mycol. 5:112-119.

18. Rowe, E. S. 1983. Lipid chain length and temperature dependence of ethanolphosphatidylcholine interactions. Biochemistry 22:3299-3305.

19. Saltveit, M. E., Jr. 1989. Effect of alcohols and their interaction with ethylene on the rip- ening of epidermal pericarp discs of tomato fruit. Plant Physiol. 90:167-174.

20. Saltveit, M. E., Jr., and Mencarelli, F. 1988. Inhibition of ethylene synthesis and action in ripening tomato fruit by ethanol vapors. J. Am. Soc. Hortic. Sci. 113:572-576.

21. Smilanick, J. L., and Fouse, D. C. 1989 Quality of nectarines stored in insecticidal low- $\mathrm{O}_{2}$ atmospheres at 5 and $15^{\circ} \mathrm{C}$. J. Am. Soc. Hortic. Sci. 114:431-436.

22. Smith, N. F., and Blomquist, M. 1970. Thermolability of dormant and germinated Monilinia fructicola and Rhizopus stolonifer spores. Phytopathology 60:866-868.

23. Smith, W. L., and Anderson, R. E. 1975. Decay control of peaches and nectarines during and after controlled atmosphere and air storage. J. Am. Soc. Hortic. Sci. 100:84-86.

24. Sommer, N. F., Fortlage, R. J., Buckley, P. M., and Maxie, E. C. 1967. Radiation-heat synergism for inactivation of market disease fungi of stone fruits. Phytopathology 57:428-433.

25. Sommer, N. F., Mitchell, F. G., Fortlage, R. J. Mayer, G., and Guillou, R. 1968. Heat treatment for brown rot control in peaches and nectarines. Blue Anchor 45:9-14.

26. Tate, K. G., and Corbin, J. B. 1978. Quiescent fruit infections of peach, apricot, and plum in New Zealand caused by the brown rot fungus Sclerotinia fructicola. N.Z. J. Exp. Agric. 6:319-325.

27. Wade, G. C. 1956. Investigations of brown rot of apricots caused by Sclerotinia fructicola (Wint.) Rehm. I. The occurrence of latent infection in fruit. Austral. J. Agric. Res. 7:504515.

28. Wells, J. M. 1971. Postharvest hot water and fungicide treatments for reduction of decay of California peaches, plums, and nectarines. U. S. Dept. of Agric., Agric. Mark. Res. Rep. No. 908. 